\title{
NONLINEAR FILTERING OF NOISY CONTRAST IMAGES BASED ON THE GENERALIZED METHOD OF THE LEAST ABSOLUTE VALUES
}

\author{
V. A. Surin ${ }^{1}$, surinva@susu.ru, \\ A. N. Tyrsin ${ }^{2,3}$, at2001@yandex.ru. \\ ${ }^{1}$ South Ural State University, Chelyabinsk, Russian Federation. \\ 2 Scientific and Engineering Center "Reliability and Resource of Large Systems and \\ Machines"UB RAS, Yekaterinburg, Russian Federation. \\ ${ }^{3}$ Ural Federal University, Yekaterinburg, Russian Federation.
}

\begin{abstract}
In article the nonlinear smoothing filter which is based on the generalized method of least absolute value is described. Comparison with other known filters of smoothing on real images is lead. Strengths and weaknesses of the given filter are revealed. As a result of experiments it is shown that smoothing by the filter on the basis of the generalized method of the least absolute values eliminates noise on overfall more effectively.

Keywords: contrast image; contrast boundary; model; digital processing; noise reduction; generalized method of least absolute values; GMLAM.
\end{abstract}

\section{Introduction}

Now digital photo and video devices practically forced out analog devices. Despite a number of advantages, digital images formation devices are not ideal and they also have errors of measurements as any metering device. As a result the created image consists of the useful image and digital noise in the form of the imposed mask from pixels of casual color and brightness [1].

Improving the quality of digital images is one of the most important tasks in digital image processing. It is solved mainly with the help of different image filtering algorithms [1-4]. However, despite the variety of digital filtering algorithms, they are usually heuristic. This is especially noticeable in noise reduction in contrast images. The main reason is the insufficient research on the properties of digital noise in contrast images.

Many authors [5-7] specify that distribution of digital noise submits to the Gaussian distribution law, without having conducted researches and without consideration of the features of the images. As a result noise suppression algorithms which well work with a normal distribution of noise, the generally linear algorithms are usually offered. However, as it is noted in [8], the mathematical tractability that is typical for working with Gaussian noise models is so convenient that it often results in Gaussian models being used in situations in which they are marginally applicable at best. Such ambiguity of statements of rather statistical properties of the additive noise speaks about poor research of the matter.

In [9] it is shown that the additive noise in digital contrast images has non-linear character. On boundary of overfall dispersion of noise has different size, and on boundary of minimum brightness noise has not Gaussian nature of distribution. It happens because of the nonlinear nature of emergence of noise. Use of the linear digital filters for contrast images is not effective as leads to a blurring of contours of details in contrast images that reduces sharpness of the image and worsens its quality. The applied non-linear noise 
reduction algorithms on the basis of the median filtration offered by John Tukey [10] for contrast images have shortcomings, because median filters are sensitive to sharp changes in the image brightness. Various modifications of median filtering [11-13] in some cases achieve gain as compared with conventional median filtering, but they are not enough formalized and usually require additional a priori information. Thus, for contrast images, digital filtering models are used, but their adequacy is not sufficiently investigated. This causes inefficiency of developed digital filtering algorithms, their operability for separate classes of images without establishing of the reasons of it.

In [14] it is proposed to carry out filtering of contrast images by means of nonlinear smoothing based on the generalized method of the least absolute values (GMLAV) [15]. A certain positive effect is achieved and in [16] the model of the nonlinear filter based on GMLAV was proposed.

The aim of the article consists in creation of the filter for digital processing of contrast images based of the model offered in [16] and approbation this filter on real data.

\section{Description of Mathematical Model}

Loss function of the smoothing transform has been chosen being guided by the results described in [9]. There the role of a loss function is played by the arc tangent function proposed in [14]:

$$
\rho_{0}(x)=\operatorname{arctg}(|x|) \text {. }
$$

However, the direct application of equation (1) does not account for the specific features of the image and overfall, such as noise variance and degree of contrast of the overfall. As achievement by loss function (1) of the limit can happen too quickly, or insufficiently quickly, in both cases it will result in low efficiency of estimates and even to their shift. Therefore, instead of equation (1), we use the loss function of the form:

$$
\rho(x)=\operatorname{arctg}\left(\frac{|x|^{\alpha}}{\beta}\right),
$$

where $\alpha>0$ and $\beta>0$ are parameters selected on the basis of the image and variation characteristics: $\sigma$ is the standard deviation (level) of noise in the selected region of the image, $A$ and $B$ are the lower and upper boundaries of the brightness level of the overfall, and $h=B-A$ is the difference between the upper and lower boundary of the overfall brightness (degree of contrast of the overfall).

The model assumes the variation of two parameters of the loss function (2) as a function of the degree of contrast and noise level. To consider not Gaussian distributions of noise near the lower boundary of brightness it is necessary to use convex property of loss function, therefore to choose parameter $\alpha \in(0 ; 1)$. In the case of Gaussian distribution of noise, use the convex-concave function when $\alpha \in[1 ; 2)$. The $\beta$ would change depending on change of the noise level $\sigma$ and the value of the brightness variation $h$.

It is necessary to choose the functions $\alpha=\alpha(\sigma, h, A), \beta=\beta(\sigma, h, A)$ so that the result of smoothing by the GMLAV filter with the loss function (2) is close to the best result.

During the numerical experiment which was made by means of the Monte-Carlo method of statistical tests the following dependencies have been received for $\alpha$ and $\beta$ : 


$$
\begin{aligned}
& \alpha= \begin{cases}0,7, & A=0, \\
0,7 \cdot\left(\frac{3 \sigma-A}{3 \sigma}\right)+1,6 \cdot\left(1-\frac{3 \sigma-A}{3 \sigma}\right), & 0<A \leq 3 \sigma \\
1,6, & A>3 \sigma\end{cases} \\
& \beta=10+\frac{\sigma \cdot h}{100} .
\end{aligned}
$$

For simplification, we consider not a color image, but an image in the form of gray scale, which gives 256 possible values of pixel brightness, where 0 is black and 255 is white. In this case, the filtering procedure is described by the expression

$$
\hat{y}_{i}=\underset{a_{i}}{\arg \min } \sum_{j=i-l}^{i+l} \rho\left(\left|y_{j}-a_{i}\right|\right),
$$

where $y_{i}$ and $\hat{y}_{i}$ are the actual values of the image pixel brightness and the values of the image pixel brightness, which are smoothed using the GMLAV filter; $i$ is the pixel number. The filter aperture is $L=2 l+1$.

As assessment of quality of filtration it is used the average linear deviation between the ideal image and the smoothed one, which is calculated as:

$$
d=\frac{1}{N} \sum_{i=1}^{N}\left|\hat{y}_{i}-f_{i}\right|,
$$

where $f_{i}$ denotes the ideal (noise-free) values of the image pixel brightness, $N$ is number of the pixels in the image processed by smoothing.

\section{Description of the Filtering Algorithm}

The preliminary analysis of the image is carried out for reception of the information from the image necessary for filter work. It is necessary to execute following steps:

1. Search approximate an arrangement of contrast boundaries in the image (Creation of boundaries map).

2. Creation of gradients map.

3. Noise level search in the image.

Let's consider each of steps in more details. Search of an approximate arrangement of contrast boundaries in the image can be lead, applying the Kenny's boundary detector. Thus, we receive a mask where on a black background note contrast borders by white lines in width in 1 pixel (Fig. 1). Its size (length, width) is equal to the primary image.

The given mask is necessary for correct orientation of the aperture to the image in such a way as to the aperture was perpendicular contrast lines.

The gradients map (Fig. 2) is under construction that at filter work it was possible to choose correctly parameters $h$ and $A$, necessary for the equation (3). The gradients map represents strongly smoothed image where contrast boundaries are kept. We will smooth our noisy image the median filter with the big aperture so that the pixels getting to the aperture, did not cross contrast boundaries. It is necessary that pixels on the one hand boundary did not influence pixels on the other hand. Such smoothing will wash away details on the image, but will allow to clean noise completely almost. In this case parameters $A$ and $B$ will choose correctly. 

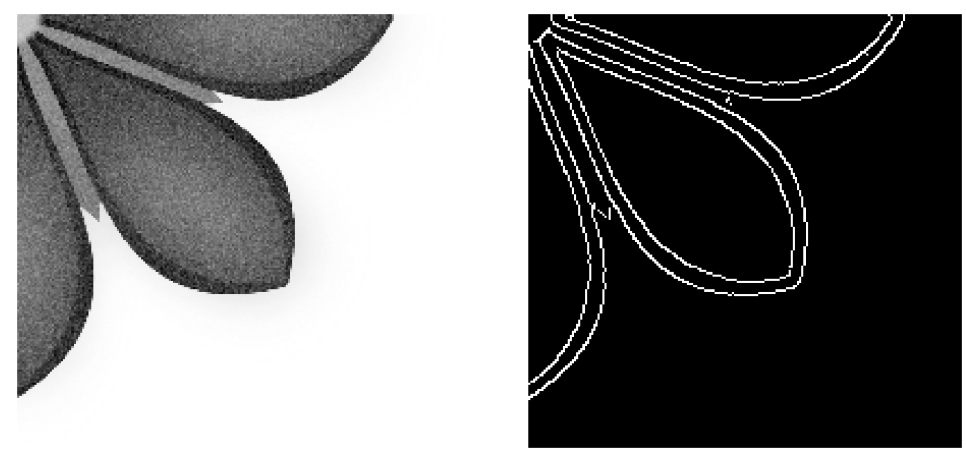

Fig. 1. Left - the initial noisy image, right - the map of borders of the initial noisy image

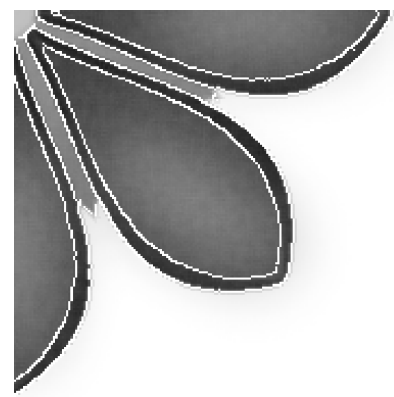

Fig. 2. Gradients map

Noise level is the parameter is necessary for the equation (3). Noise level search can be lead in two ways. The first way consists in finding a monotonous area of the necessary size and to calculate noise dispersion in it. For correct calculation of a dispersion the area should be concerning big (not less than 400 pixels). However find a similar area on the image it can to appear a complicated problem. There is a problem of search of such area. Besides at the analysis the noisy area with a uniform gradient of the initial image can give the big noise dispersion, than is actually.

The second way of search of noise level in the image is based on comparison of the initial noisy image and the filtered image by simple median filter. The estimation turns out by compare of two images pixel by pixel. Modules of a difference of brightness of two images develop and division on total amount of pixels in the image. Further there is an average brightness of noisy images. On the basis of the data about of noise distribution [9], we can calculate the amplifier gain of noise (6). It is required to calculate average brightness of the image. The more brightness, the noise becomes less. However the model of the non-linear filter paid off proceeding from noise level size at the minimum brightness. Owing to what the amplifier gain of noise calculating like:

$$
\text { coef }=\frac{255}{255-\bar{y}}=1+\frac{\bar{y}}{255-\bar{y}}
$$

where 255 is a maximum level of brightness, $\bar{y}=\frac{1}{n \cdot m} \sum_{i=1}^{n} \sum_{j=1}^{m} y_{i j}$ is an average level of brightness in the image, $n$ and $m$ are height and width of the image in pixels.

Having calculated the amplifier gain of noise, we can calculate noise level in the image: 


$$
\sigma=\operatorname{coef} \cdot \frac{1}{n \cdot m} \sum_{i=1}^{n} \sum_{j=1}^{m}\left|\hat{y}_{i j}-y_{i j}\right| .
$$

The algorithm of a filtration is started directly, when all necessary parameters for (3) will be received. Passing on a mask with the boundaries of contrast noted on it, pixels on the boundaries and in immediate proximity from contrast boundaries get out for a filtration. Pixels which will be smoothed by the filter, settle down on the distance which is not exceeding half of the aperture plus 1 pixel from boundaries of contrast (Fig. 3).

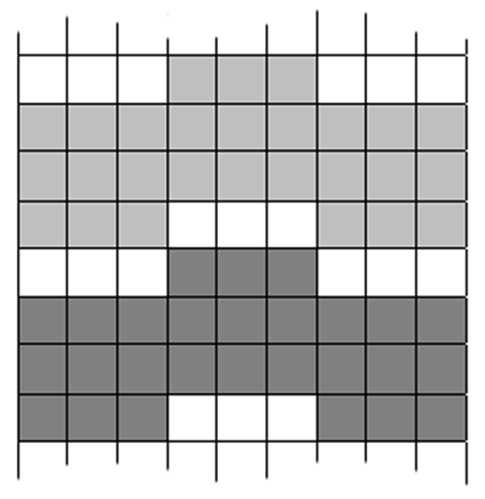

- area of processing

- alleged line of contrast

- area of processing

Fig. 3. Filtration area

The aperture can settle down in space in 4 ways (Fig. 4):
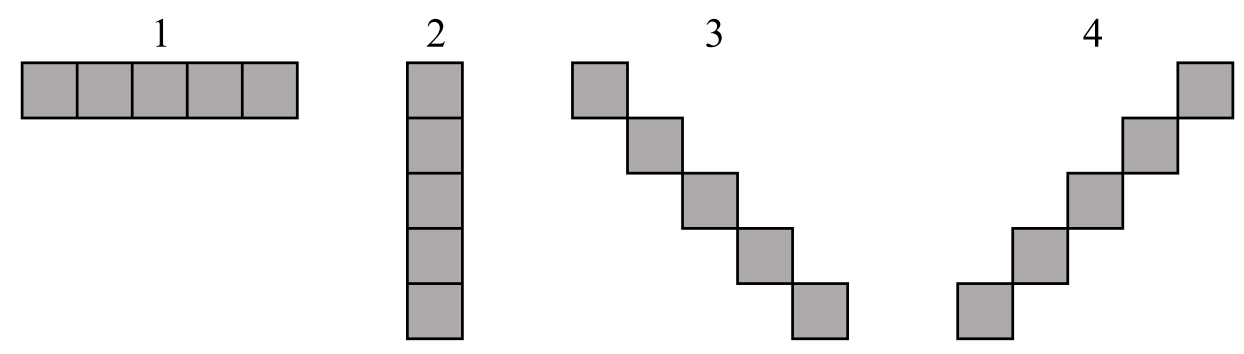

Fig. 4. Possible kinds of the aperture

Choice of correct orientation of the aperture it is made on an arrangement of the nearest pixels in a boundaries map. Total 20 variants which will distributed in groups where for all variants in one group there will correspond one arrangement of the aperture (Fig. 5 - Fig. 8):
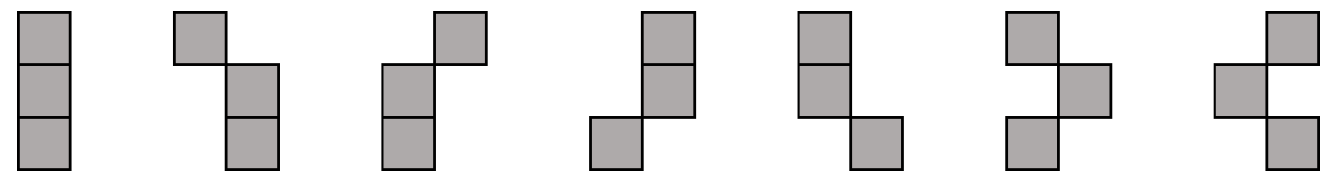

Fig. 5. Variants of an arrangement of pixels of contrast boundary to which the aperture of a kind $\ll 1 »$ is applied

Having chosen the necessary aperture, smoothing is made under the equation (4). 

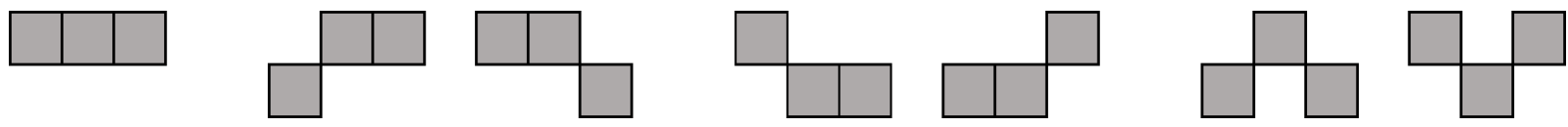

Fig. 6. Variants of an arrangement of pixels of contrast boundary to which the aperture of a kind $\ll 2 »$ is applied
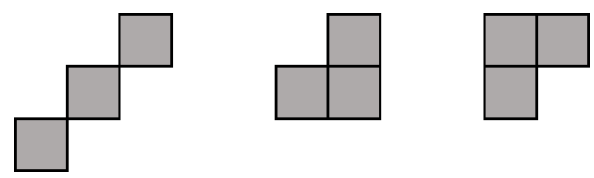

Fig. 7. Variants of an arrangement of pixels of contrast boundary to which the aperture of a kind «3» is applied
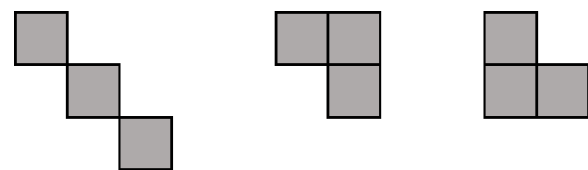

Fig. 8. Variants of an arrangement of pixels of contrast boundary to which the aperture of a kind $« 4 »$ is applied

\section{Results of Filter's Work}

Result of filter's work is the filtered image. Following images are showed: initial, noisy and filtered (Fig. 9):

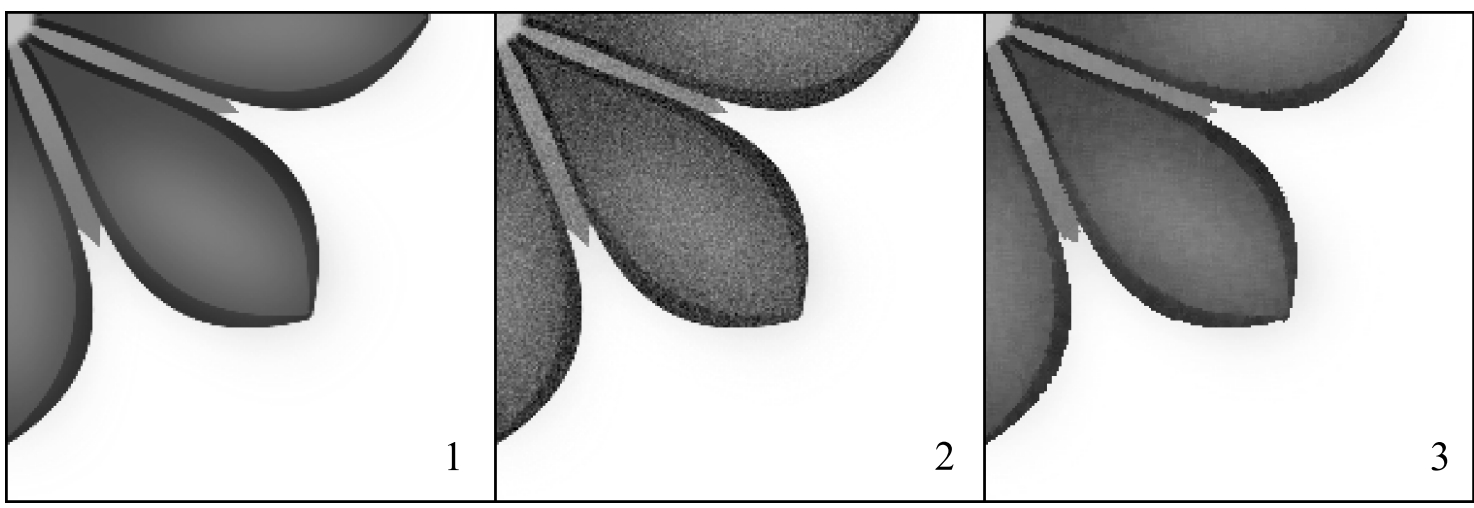

Fig. 9. 1 - initial noise-free image; 2 - noisy image; 3 - filtered by filter on loss function (2)

For comparison images after processing by various methods of smoothing are showed (Fig. 10).

At a filtration of real contrast noisy images (Fig. 11) the filter allows to keep sharp boundary without its diffusion. Visually to estimate efficiency of smoothing, we will filter the real noisy image by means of various filters: the linear averaging filter, the median filter, the filter based on loss function (2). In Fig. 12 the areas filtered by various filters are resulted at is increased. 


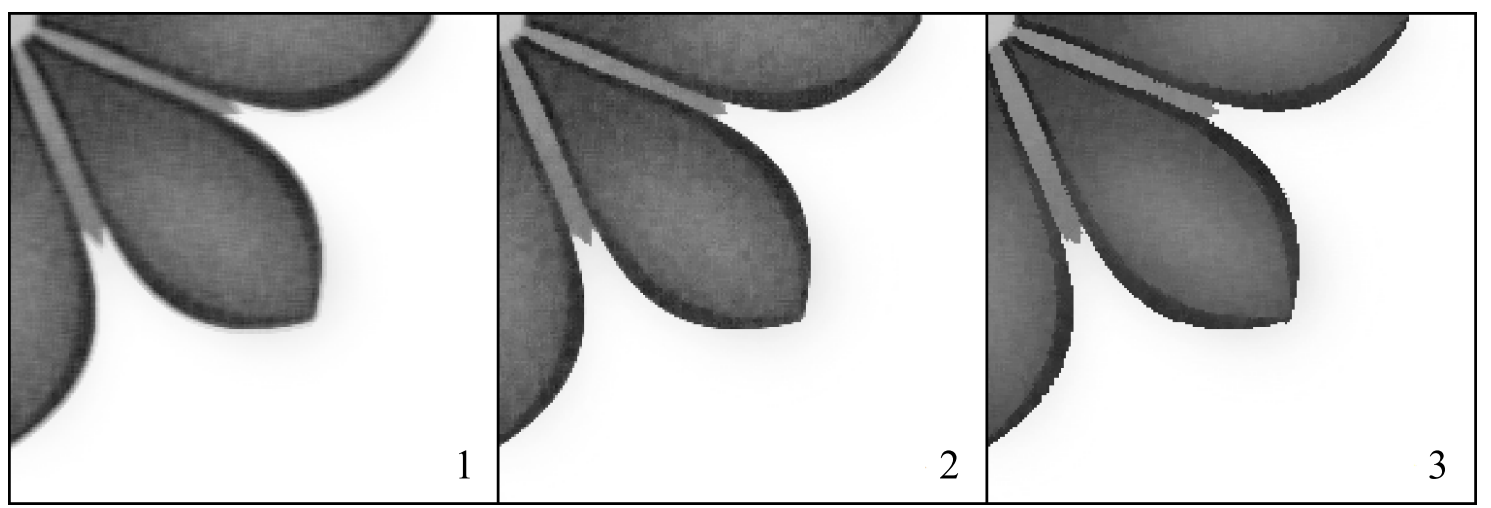

Fig. 10. The image filtered by means of various filters: 1 - linear averaging filter; 2 - median filter; 3 - filter based on loss function (2)
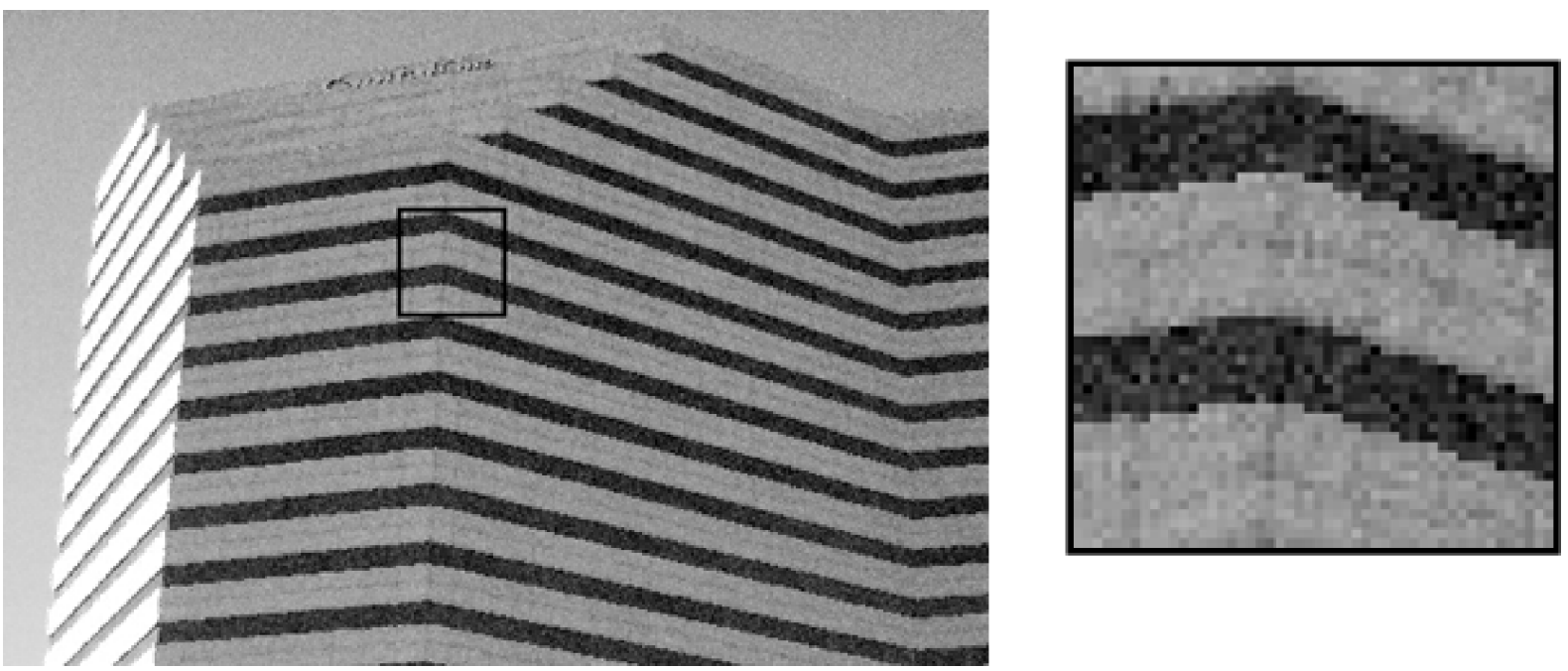

Fig. 11. The real noisy image of a building at the left; the increased area allocated with a square framework on the image, on the right
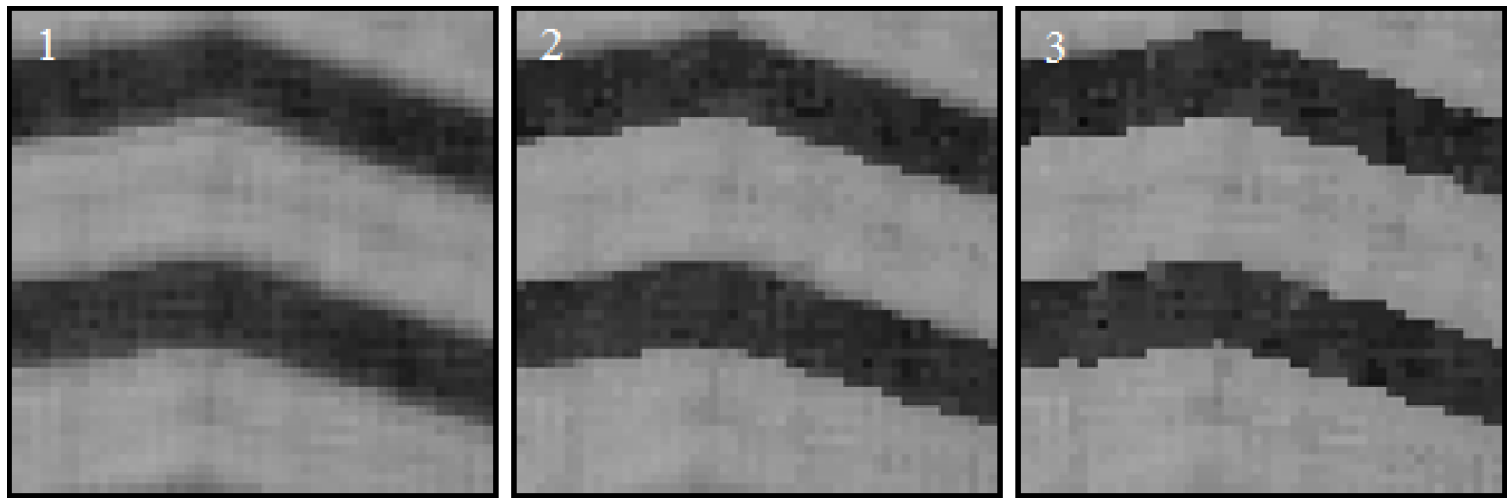

Fig. 12. The filtered images of the allocated area by: 1 - linear averaging filter; 2 - median filter; 3 - filter based on loss function (2)

At a filtration of images in which for any reasons contrast borders have been blurred, the filter allows to restore contrast. For test we take initial image of a building without 
noise and we will blur contrast borders. Further we will spend a filtration of the median and the GMLAV filter. Results, in the form of the increased area of the image, are presented in Fig. 13.
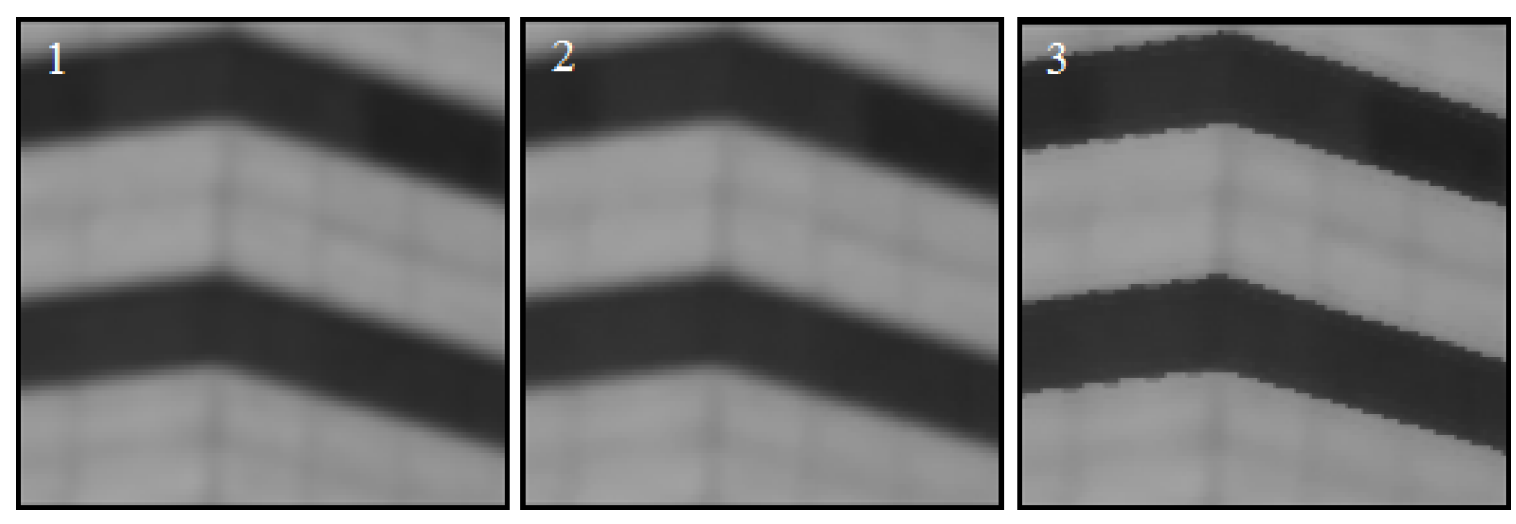

Fig. 13. The increased areas of images: 1 - initial noise-free image; 2 - filtered by using median filter; 3 - filtered by using filter based on loss function (2)

\section{The Analysis of Results}

For comparison of various methods of smoothing of images we will smooth 3 images with noise levels 10, 20, 30 and 40 by various filters. We will compare the image processed by filters and initial images without noise under the equation (5) and to write down results in Table. Let's compare only those pixels which are in immediate proximity from contrast boundaries, instead of full image.

Table

\begin{tabular}{|c|c|l|l|l|}
\hline \multirow{2}{*}{ Image } & \multirow{2}{*}{ Noise level } & \multicolumn{3}{|c|}{ Filter } \\
\cline { 3 - 5 } & & \multicolumn{1}{|c|}{1} & \multicolumn{1}{|c|}{2} & \multicolumn{1}{|c|}{3} \\
\hline \multirow{4}{*}{1} & 10 & 20,09 & 3,83 & 3,41 \\
\cline { 2 - 5 } & 20 & 20,65 & 6,92 & 6,19 \\
\cline { 2 - 5 } & 30 & 21,44 & 9,79 & 9,50 \\
\cline { 2 - 5 } & 40 & 20,87 & 12,06 & 11,94 \\
\hline \multirow{4}{*}{2} & 10 & 14.74 & 6,75 & 5,95 \\
\cline { 2 - 5 } & 20 & 15,02 & 8,84 & 8,22 \\
\cline { 2 - 5 } & 30 & 15,71 & 11,23 & 10,71 \\
\cline { 2 - 5 } & 40 & 16,15 & 13,13 & 12,78 \\
\hline \multirow{4}{*}{3} & 10 & 24,66 & 3,81 & 3,19 \\
\cline { 2 - 5 } & 20 & 25,93 & 6,08 & 4,93 \\
\cline { 2 - 5 } & 30 & 26,86 & 8,31 & 7,09 \\
\cline { 2 - 5 } & 40 & 24,11 & 10,58 & 9,67 \\
\hline
\end{tabular}

Proceeding from the results received in the table 1 it is possible to conclude that linear smoothing does not approach for noise suppression in contrast images. It strongly blurred contrast boundaries in image at any noise level. 
The filter based on GMLAV gives a profit at a filtration in comparison with the median filter and allows keeping contrast on boundaries.

\section{Conclusion}

The filtration of noisy contrast images on the basis of the generalized method of the least modules, allows deleting noise from the image, keeping thus contrast borders. Quality of noise reducing by the offered method of a filtration near to contrast borders appears above, than at the linear and the median filters.

Also the non-linear filter on the basis of GMLAV allows restoring borders in those images in which for any reasons have been blurred contrast borders.

\section{References}

1. Yaroslavsky L.P. Introduction to Digital Image Processing. Moscow, Sov. Radio, 1979. (in Russian)

2. Huang T. S., Eklund J.-O., Nussbaumer G. J., et al. Two-Dimensional Digital Signal Processing. Vol. 2: Transforms and Median Filters. Berlin, Heidelberg, New York, Springer-Verlag, 1981.

3. Sheremet I.A., Rukin A.P., Lebedev V.D. Image Processing Using Integer Orthogonal Transformation Matrices. Tsifrovaya Obrabotka Signalov, 2014, no. 4, pp. 45-53. (in Russian)

4. Klochko V.K., Kuznetsov V.P. Methods of Image Reconstruction and Hardware Function Evaluation Based on a Thinned Observation Matrix. Optoelectronics, Instrumentation and Data Processing, 2016, vol. 52, no. 6, pp. 537-545. doi: $10.3103 /$ S8756699016060029.

5. Volohov V.A. [Suppression Gaussian Noise in Images Based on Principal Component Analysis and Nonlocal Processing]. Abstract of the Thesis of the Candidate of Technical Sciences: 05.12.04. Vladimir, 2012. (in Russian)

6. Mamaev N.V., Lukin A.S., Yurin D.V. Local Noise Estimation in Digital Images. Proceedings of the DSPA-2014, 2014, vol. 2, pp. 445-449. (in Russian)

7. Priorob A.L., Apalkov I.V., Bukhtoiarov S.S., Khryashev V.V. Application of Switching Median Filters for Recovery of Noisy Images. Voprosy Radioelektroniki. Seria: Obshchetekhnicheskaya, 2006, no. 4, pp. 2-8. (in Russian) available at: http://www.dspa.ru/articles/year2006/jour06_4/art06_4_1.pdf (accessed on 9 June 2018)

8. Gonzalez R.C., Woods R.E. Digital Image Processing. New Jersey, Prentice Hall, 1992.

9. Surin V.A., Tyrsin A.N. Research of Properties of Digital Noise in Contrast Images. CEUR Workshop Proceeding, 2016, vol. 1710, pp. 340-348. available at: http://ceurws.org/Vol-1710/paper34.pdf (accessed on 9 June 2018)

10. Tukey J.W. Discussion Emphasizing the Connection between Analysis of Variance and Spectrum Analysis. Technometrics, 1961, vol. 3, pp. 191-219. 
11. Abreu E., Lightstone M., Mitra S., Arakawa K. A New Efficient Approach for the Removal of Impulse Noise from Highly Corrupted Images. IEEE Trans. on Image Processing, 1996, vol. 5, no. 6, pp. 1012-1025. doi: 10.1109/83.503916

12. Chan R., Ho C., Nikolova M. Convergence of Newton's Method for a Minimization Problem in Impulse Noise Removal. J. Comput. Math., 2004, vol. 2, pp. 168-177.

13. Schulte S., Nachtegael M., De Witte V., Van der Weken D., Kerre E. A Fuzzy Impulse Noise Detection and Reduction Method. IEEE Trans. on Image Processing, 2006, vol. 15, no. 5, pp. 1153-1162. doi: 10.1109/TIP.2005.864179

14. Tyrsin A.N., Surin V.A. Non-Linear Filtering of Images on the Basis of Generalized Method of Least Absolute Values. CEUR Workshop Proceeding 3, 2014, vol. 1197, pp. $41-47$.

15. Tyrsin A.N. Robust Construction of Regression Models Based on the Generalized Least Absolute Deviations Method. Journal of Mathematical Sciences, 2006, vol. 139, issue 3, pp. 6634-6642. doi: 10.1007/s10958-006-0380-7

16. Surin V.A., Tyrsin A.N. Nonlinear Filter Model for Digital Imaging of Contrast Images, Avtometriya, 2018, vol. 54, no. 2, pp. 54-62. doi: 10.15372/AUT20180206 (in Russian).

Vladimir A. Surin, PhD Student, Department of Applied Mathematics and Programming, Institute of Natural Sciences, South Ural State University (Chelyabinsk, Russian Federation), surinva@susu.ru

Alexander N. Tyrsin, DSc (Techn), Head of Department of Applied Mathematics, Ural Energy Institute, Ural Federal University (Yekaterinburg, Russian Federation), at2001@yandex.ru

Received June 2, 2018

УДК 621.397:004.932

DOI: $10.14529 /$ jcem 180205

\title{
НЕЛИНЕЙНАЯ ФИЛЬТРАЦИЯ ЗАШУМЛЕННЫХ КОНТРАСТНЫХ ИЗОБРАЖЕНИЙ НА ОСНОВЕ ОБОБЩЕННОГО МЕТОДА НАИМЕНЬШИХ МОДУЛЕЙ
}

\author{
В. А. Сурин, А. Н. Тырсин
}

В статье описан нелинейный сглаживающий фильтр, базирующийся на основе обобщенного метода наименьших модулей. Было проведено сравнение с другими известными фильтрами сглаживания на реальных изображениях. Были выявлены сильные и слабые стороны данного фильтра. В результате экспериментов было показано, что сглаживание фильтром на основе обобщенного метода наименьших модулей более эффективно устраняет шум на перепаде.

Ключевые слова: контрастное изображение; контрастная граница; модель; иифровая обработка; подавление шума; обобщенный метод наименъших модулей; ОМНМ. 


\section{Литература}

1. Ярославский, Л.П. Введение в цифровую обработку изображений / Л.П. Ярославский. - М.: Советское радио, 1979.

2. Быстрые алгоритмы в цифровой обработке изображений / Т.С. Хуанг, Дж.-О. Эклунд, Г.Дж. Нуссбаумер и др. - М.: Радио и связь. - 1984.

3. Шеремет, И.А. Обработка изображений с помощью целочисленных ортогональных преобразующих матриц / И.А. Шеремет, А.П. Рукин, В.Д Лебедев // Цифровая обработка сигналов. - 2014. - № 4. - С. 45-53.

4. Клочко, В.К. Методы восстановления изображений и оценивания аппаратной функции по прореженной матрице наблюдений / В.К. Клочко, В.П. Кузнецов // Автометрия. - 2016. - Т. 52, № 6. - С. 12-21.

5. Волохов, В.А. Подавление гауссовского шума в изображениях на основе анализа главных компонент и нелокальной обработки / В.А. Волохов. - Автореферат дисс. ... канд. техн. наук. - Владимир: Владимирский гос. Университет им. А.Г. и Н.Г. Столетовых. - 2012.

6. Лукин, А.С. Локальная оценка уровня шума на цифровых изображениях А.С. Лукин, Н.В. Мамаев, Д.В. Юрин // Труды 16-й международной конференции "Цифровая обработка сигналов и ее применение". - 2014. - Т. 2. - С. 445-449.

7. Приоров, А.Л. Переключающийся медианный фильтр с блоком предварительного детектирования / А.Л. Приоров, И.В. Апальков, С.С. Бухтояров, В.В. Хрящев // Цифровая обработка сигналов. - 2006. - № 4. - С. 28. url: http://www.dspa.ru/articles/year2006/jour06_4/art06_4_1.pdf. (запрос 9 июня 2018)

8. Гонсалес, Р. Цифровая обработка изображений / Р. Гонсалес, Р. Вудс. - М.: Техносфера, 2005.

9. Surin, V.A. Research of Properties of Digital Noise in Contrast Images / V.A. Surin, A.N. Tyrsin // CEUR Workshop Proceeding. - 2016. - V. 1710. - P. 340-348. url: http://ceur-ws.org/Vol-1710/paper34.pdf. (запрос 9 июня 2018)

10. Tukey, J.W. Discussion Emphasizing the Connection between Analysis of Variance and Spectrum Analysis / J.W. Tukey // Technometrics. - 1961. - V. 3. - P. 191-219.

11. Abreu, E. A New Efficient Approach for the Removal of Impulse Noise from Highly Corrupted Images / E. Abreu, M. Lightstone, S. Mitra, K. Arakawa // IEEE Trans. on Image Processing. - 1996. - V. 5, № 6. - P. 1012-1025.

12. Chan, R. Convergence of Newton's Method for a Minimization Problem in Impulse Noise Removal / R. Chan, C. Ho, M. Nikolova // J. Comput. Math. - 2004. - V. 2. P. $168-177$.

13. Schulte, S. A Fuzzy Impulse Noise Detection and Reduction Method / S. Schulte, M. Nachtegael, V. De Witte, D. van der Weken, E. Kerre // IEEE Trans. on image processing. -2006 . - V. 15, № 5. - P. 1153-1162.

14. Tyrsin, A.N. Non-Linear Filtering of Images on the Basis of Generalized Method of Least Absolute Values / A.N. Tyrsin, V.A. Surin // CEUR-WS.org. - 2014. V. 1197. - P. 41-47. 
15. Tyrsin, A.N. Robust Construction of Regression Models Based on the Generalized Least Absolute Deviations Method / A.N. Tyrsin // Journal of Mathematical Sciences. - 2006. - V. 139, issue 3. - P. 6634-6642.

16. Сурин, В.А. Модель нелинейного фильтра для цифровой обработки контрастных изображений / В.А. Сурин, А.Н. Тырсин // Автометрия. - 2018. - Т. 54, № 2. C. $54-62$.

Сурин Владимир Анатольевич, аспирант, кафедра прикладной математики и программирования, институт естественных и точных наук, Южно-Уральский государственный университет (ә. Челябинск, Российская Федерация), surinva@susu.ru

Тырсин Александр Николаевич, доктор технических наук, заведующий кафедрой прикладной математики, Уральский энергетический институт, Уральский федеральный университет (г. Екатеринбург, Российская Федерация), at2001@yаndex.ru

Поступила в редакцию 2 июня 2018 г. 